\title{
Assessing Jordan B. Peterson's contribution to the psychology of wellbeing: \\ A book review of 12 Rules for Life
}

\author{
Paul T. P. Wong
}

\begin{abstract}
This article first critically examines the Jordan B. Peterson phenomenon and the popular appeal of his book, 12 Rules for Life. It then evaluates this book's contribution to the psychology of wellbeing in four areas: (a) the psychology of religious values, (b) the importance of personal responsibility, (c) accepting suffering as the foundation for wellbeing, and (d) the process of finding one's meaning based on personal sacrifice and negotiating a balance between chaos and order. Finally, it examines empirical support for his ideas, as well as his contribution to the emerging domain of existential positive psychology. Finally, implications for the future of positive psychology research and interventions are discussed.
\end{abstract}

\section{Introduction}

Jordan Peterson is an enigma. At present, he is the best-known public psychologist (Murphy, 2018), but also the least understood, because of the opacity of his views (Johnson, 2018). "It can be tough to parse the Peterson phenomenon. For one thing, it seems as if there are multiple Petersons, each appealing to, or in some cases alienating, separate audiences" (Bartlett, 2018). Peterson enjoys the status of a rock star in psychology, giving interviews at almost all the major talk shows, speaking to sold-out theatres in major cities around the Western world, and selling more than two million copies of his 12 Rules for Life in less than a year. However, for all his media and financial successes, he is also the most hated psychologist for his political and cultural views.

Those who hate him either dismiss his book offhand, or read it critically in order to discredit it. He has alienated most of his colleagues (see Schiff, 2018) and offended a huge swath of academia. Even some of his academic friends have carefully distanced themselves from him, afraid of being painted by the same brush. He used to speak regularly at the Meaning Conferences that I organize (www.meaning.ca), but now, a few of my colleagues have even criticized me for daring to speak about his recent book at the 2018 Meaning Conference (Wong, 2018a). 
Slayback (2018) has provided a partial explanation of why Peterson has become hated by so many intellectuals - the main reason is his intellectual arrogance and courage in attacking his colleagues in the humanity and social sciences departments for their ideology. Another reason is that he refuses to play the traditional academic game of research and publications in refereed journals, and yet he is able to achieve greater success through mastering social media, especially YouTube, with more than 1.6 million subscribers and more than 79.8 million views at time of writing (Social Blade, 2018).

\section{The Peterson phenomenon demands attention}

About $80 \%$ of Peterson's admirers are males, but for very different reasons, as reported in Maclean's (Köhler, 2018). Similarly, several of my clients from different walks of life have also been helped by Peterson's 12 Rules for Life; some even told me that his book had been more helpful than positive psychology books. Numerous Jordan Peterson study groups and Meetup groups have sprung up spontaneously to better understand his 12 Rules for Life, providing empirical support to Peterson's appeal. His self-authoring program with Daniel M. Higgins and Robert O. Pihl (www.selfauthoring.com) is based on the same theme of helping people sort themselves out; this program has helped numerous people (Meadows, 2018; Schippers, Scheepers, \& Peterson, 2015).

\section{Peterson is a cultural phenomenon}

Peterson is an international bestseller and a cultural phenomenon who demands our attention. In spite of all the criticisms directed against him and his 12 Rules for Life because of his cultural and political views, it is an undeniable fact that many people have found help from reading his book or doing his self-authoring program. As psychologists, especially those who identify as positive psychologists, we need to ask: What is in this book that has attracted and helped so many people? What does this book offer that is different or missing in the self-help books authored by positive psychologists? It behooves us to assess Peterson's book in an objective manner so that we can find something to enrich our research and practice of the psychology of wellbeing.

I believe that Peterson's meteoric rise to fame was no accident-it was a phenomenon waiting to happen. Several emerging currents have conflated to create a perfect storm, and Peterson happened to be just the right person in the right place at the right time to become the conduit of all the pent-up feelings of dissatisfaction with political correctness and secular materialism, in addition to the yearning for meaning and spirituality in these chaotic times. Peterson had all the necessary qualities and skills to pull off a one-man coup: a sterling academic background, a charismatic camera and stage presence, and a large and wide-ranging intellect, as attested by hundreds of hours of his engaging lectures and debates.

If we dismiss his work simply because he is a polarizing and controversial figure, we will do a disservice to the discipline of psychology. It is legitimate to ask ourselves why he is able to attract and impact so many people, in spite of the fact that his 12 Rules for Life is a complicated 
and frustrating book to read. Unlike other self-help books, 12 Rules for Life covers a wide range of subjects, from theology and history, to evolutionary biology and personality psychology. It also includes numerous digressions with his rants against identity politics, cultural Marxism, and postmodern feminism. In this review, I will assess Peterson's contribution to the psychology of meaning and wellbeing. Therefore, I will not get involved in the maelstrom of the cultural warfare swirling around him.

\section{A preliminary analysis of Peterson's popular appeal}

My preliminary analysis suggests three main reasons for the appeal of Peterson's 12 Rules for Life. First of all, his straight-shooting, no-nonsense style of writing is a breath of fresh air for young people educated in a campus climate of "coddling the American mind" (Lukianoff \& Haidt, 2018); they welcome his authentic voice telling them the brutal truth about themselves and about the world in which they live. They respond positively to his pull-up-your-bootstraps talk, as if they have been longing to hear such guidance from the authoritative father figure they never had.

Secondly, he meets them where they are-at the bottom of a dominance hierarchy, a place of despair, confusion, and resentment. He speaks with empathy and understanding, but does not give them easy answers or phony promises. Instead, he shows them a way out of their miseries on the condition that they aim at the highest good and make the necessary sacrifices for a better future.

Thirdly, he lays down concrete steps to guide them to transform their lives and achieve their heaven on earth. Although there is nothing new in his advice, which is based on traditional Judeo-Christian values, he has a fresh new way of discussing these issues, and there is a coherent and deep conceptual framework for the 12 rules as a package. He is also able to add gravity and existential significance to scientific findings. For example, he is able to elevate Mischel's (1966) marshmallow study of delayed gratification to a higher spiritual plane of making self-sacrifice for the greater good, as exemplified by Jesus' death on the cross.

\section{Peterson's obfuscating writing style}

Contrary to his own advice to be clear and precise in speech and thought, Peterson's writing is often ambiguous, verbose, and guilty of tautology-saying the same thing at an increasingly deeper level. Critics may dismiss his writing as gobbledygook dressed up in pseudoprofundity. However, his admirers find his words tumbling out like cascading ocean waves, inspiring them to look and think about many important issues in a deeper way. Readers can form their own opinions by reading a quote from his overture that illustrates his recursive and opaque writing style:

How could the world be freed from the terrible dilemma of conflict, on the one hand, and psychological and social dissolution, on the other? The answer was this: through the elevation and development of the individual, and through the 
willingness of everyone to shoulder the burden of Being and to take the heroic path. We must each adopt as much responsibility as possible for individual life, society and the world. We must each tell the truth and repair what is in disrepair and break down and recreate what is old and outdated. It is in this manner that we can and must reduce the suffering that poisons the world. It's asking a lot. It's asking for everything (Peterson, 2018, p. xxxiii).

\section{Overall assessment}

\subsection{Peterson's unique view on the psychology of religious values}

At the 2016 Meaning Conference, Peterson (2016) had already stressed the danger of nihilism and totalitarianism following the destruction of traditional religious values by rationalism and empiricism. He pointed out that neither a return to the past, nor individualistic heroism in creating meaning and value is the proper solution. Instead, he proposed an alternative approach based on the intersection of nature, culture, and individuals.

This approach recognizes that religious and cultural thinking is an important source of "mythological truths" evolving over aeons and passed on to us as collective unconsciousness. The values that enable us to survive individually and collectively are based on these religious or mythological truths that teach us how to live meaningfully, in spite of the tragedies of life.

In the first two chapters, Peterson lays down the two pillars of truth. First, science is about the truths or empirical laws of things in nature; second, religion is the narrative of the laws of values or moral actions in human life. God or some sort of higher power is operating in both spheres of reality. We need both domains to provide an adequate account of human existence. Like many of the past luminaries in science (e.g., Francis Bacon, Isaac Newton, Albert Einstein) and many scientists of the present day (Quester, 2018), Peterson believes in the existence of God as the grounding for moral laws, because science, by virtue of its nature, is not capable of providing a moral foundation or answering the ultimate question about God's existence; in fact, even modern science itself faces a moral challenge (Levin, 2006).

Both scientific research (Emmons, 2003; Hill \& Pargament, 2003; Koenig, 1998; Routledge, 2018) and philosophy (Carkner, 2016; Taylor, 2007) have presented a compelling case that religious beliefs are not only rational but also vital for our wellbeing. Peterson believes our religious worldviews or assumptions determine what the world will reveal to us. "Now you're on a whole different kind of trajectory ... You make the necessary sacrifice, and allow a whole new world of possibility, hidden from you because of your previous ambition, to reveal itself" (Peterson, 2018, p. 100).

Unlike other positive psychologists, Peterson believes that certain preconditions need to be met before one can live a meaningful life. If we choose to believe in transcendental values, "meaning is something that comes upon you, of its own accord" (Peterson, 2018, p. 200). In other words, meaning is something that will be revealed to people who are ready-who have the right attitudes and values. "You can set up the preconditions, you can follow meaning, 
when it manifests itself, but you cannot simply produce it, as an act of will" (Peterson, 2018, p. 200).

This view is exactly the same as that expressed by Frankl $(1985,1986)$, who has long insisted that meaning is discovered rather than created simply by arbitrary action. More specifically, meaning can be discovered only if one has the meaning-mindset (Wong, 2012a) and the motivation for self-transcendence (Wong, 2014a; Wong \& Reilly, 2017). Research has shown that worldview is important in shaping not only our perceptions, but also how science is done (Medin, Lee, \& Bang, 2014). Worldview is also an important factor in eudaimonic happiness (Braaten \& Huta, 2018).

Peterson's rules are based on ancient wisdom, especially as found in the Bible. He argues that by their very nature, human beings need to be guided by moral rules and spiritual values in order to survive and thrive in a world full of temptations and evils; they ignore these rules at their peril. "We require rules, standards, values - alone and together... We need to stay on the straight and narrow path" (Peterson, 2018, p. xxxiv). Such traditionalist teaching can be reassuring to those who feel confused and lost in the postmodern culture of relativism, secularism, and nihilism.

\subsection{Peterson's contribution to existential positive psychology}

Life is a struggle, whether it is for mere survival or for achieving a good life. Given the individual differences in circumstances and life goals, there are infinite ways to go through life; science cannot predict which path one chooses, nor which path leads to success, however one defines it.

But human experience, both personal and collective, current and historical, confirms the ultimate truth that life is full of struggle and suffering, only some of which is avoidable through one's actions. Therefore, it seems reasonable for Peterson to assert that the undeniable reality of suffering must be the foundation for living a meaningful life. Stated simply, Peterson raises a fundamental question: Given the reality of suffering, what activity will you pursue today which will be not only good for you, but also for those around you and beyond? What activity will you pursue that will be good for you not just for today, but also for tomorrow, days after tomorrow, and forever?

This is the fundamental question of meaning and purpose or how we should live as human beings. Peterson's answer to this fundamental question is also surprisingly simple: You have a moral obligation or a responsibility to yourself and your loved ones to aim at the greatest good according to your conscience and best understanding, then to pursue it each day with selfdiscipline, integrity, and courage. This is a narrow and difficult path demanding hard work and self-sacrifice, but the alternative is to waste your life in misery or despair. This sounds like a reasonable proposition worthy of serious consideration. 
The whole book is an elaboration of why and how we can walk this narrow path of making self-sacrifice to ameliorate unnecessary suffering and bring a little bit of heaven to our earth. His entire project is about following certain time-tested rules based on the two supreme values of love and truth, defined and elaborated in various chapters of this book. Here is a brief summary of Peterson's 12 rules in his cryptic style:

Life is suffering.

Love is the desire to see unnecessary suffering ameliorated.

Truth is the handmaiden of love.

Dialogue is the pathway to truth.

Humility is recognition of personal insufficiency and the willingness to learn.

To learn is to die voluntarily and be born again, in ways great and small.

So, speech must be untrammeled, so that dialogue can take place,

so that we can all humbly learn,

so that truth can serve love,

so that suffering can be ameliorated,

so that we can all stumble forward to the Kingdom of God (Peterson, 2017).

Although Peterson makes heavy use of Jungian archetypes, his approach of taking personal responsibility for finding meaning in suffering is very similar to Viktor Frankl's logotherapy (1985) and existential positive psychology (Wong, 2016a, 2016b), which is also known as second wave positive psychology (PP 2.0) (Ivtzan, Lomas, Hefferon, \& Worth, 2015; Wong, 2011). The main tenet of existential positive psychology is that one can achieve wellbeing only through confronting the dark side of human existence and a dialectic process of finding meaning in ameliorating suffering.

Living each day fully does not simply mean focusing only on the present moment. It means having the courage to "place faith in God's Heavenly Kingdom, and the truth. That's a conscious decision to presume the primary goodness of Being... Once you are aligned with the heavens, you can concentrate on the day" (Peterson, 2018, p. 351). This calls for the use of the double-vision strategy in meaning therapy (Wong, 2016b) - to keep one eye on what we can do at the moment, and the other eye on our spiritual vision of heaven. Peterson also challenges us to "repair what is in disorder, and make what is already good better" (Peterson, 2018, p. 351); this dual-systems approach (Wong, 2012b) is the most effective way to make you stronger.

Drawing from Jungian psychology, Peterson encourages his readers not only to integrate their shadow with the ego (the apprentice-piece), but also their animus (autonomy and dominance) with anima (communion and relationships) (the master-piece). Both personal development and societal development depend on the transcendental function of integrating opposites with respect to race, gender, and sexual orientation, and our capacities for good and evil. It is unfortunate that most readers do not understand the communion focus of his last four chapters, culminating in the symbolic act of gently petting a street cat. 
Peterson's psychology is clearly influenced by the Daoist concept of yin-yang. This is another basic tenet of existential positive psychology. Everything in life exists in polarities, and one needs to navigate a balance- between order and chaos, happiness and sorrow, good and evilin order to survive and thrive in a harsh and competitive world (Lomas \& Ivtzan, 2016; Wong, 2016c).

Peterson challenges us to follow the narrow line between chaos and order or between yin and yang; this requires us to restore our belief in God as the source and foundation of our morality and stay away from nihilism and all kinds of totalitarian ideologies such as Marxism, postmodernism, rationalism, and scientism.

Unfortunately, neither mainstream psychology nor positive psychology has fully recognized the importance of embracing the dark side of life and the dialectic nature of wellbeing. One of the major contributions from Peterson is that he is able to make a compelling case for these concepts, as I will show later on.

\section{Overview of the book}

Peterson gives advice on how to maintain a proper posture, make friends, raise children, listen, talk, self-improve, and so on. He explains why we need to explore the opposing forces of chaos and order and why we should choose order as the secure base in order to venture out and tolerate chaos, and thereby grow.

\subsection{Chaos vs. order \\ In Peterson's words:}

Chaos is the despair and horror when you feel you've been profoundly betrayed. It's the place you end up when things fall apart, when your dreams die, your career collapses, or your marriage ends.... Order is the place and time where the oft-invisible axioms you live by organize your experience and your actions so that what should happen does happen (Peterson, 2018, pp. 35, 37).

However, "in its positive guise, chaos is possibility itself, the source of ideas, the mysterious realm of gestation and birth. As a negative force, it's the impenetrable darkness of a cave and the accident by the side of the road" (p. 42). Thus, even in times of chaos, there is the opportunity of rebirth, transformation, and return to order; this will happen when we choose to accept our need for some time-tested ancient wisdom and traditional moral rules. Again, this is the Daoist principle of yin-yang operating to restore balance-in-living.

Thus, meaning in life does not come from the straightforward pursuit of one's ideal career and relationships, as advocated by so many positive psychologists. Rather, meaning comes from wisely navigating between security and risk, success and failure, or familiar grounds of 
established knowledge and unproven new possibilities until one finds one's way (Wong, 2012b).

I agree with Peterson's understanding of the world: "We eternally inhabit order, surrounded by chaos. We eternally occupy known territory, surrounded by the unknown. We experience meaningful engagement when we mediate appropriately between them. ... Chaos and order make up the eternal, transcendent environment of the living" (Peterson, 2018, p. 43). This is the world of transcendence and polarity (Wong, 2016c).

We mess up our lives when we yield to nihilism and chaos. We experience meaning and mature happiness "from our deepest being" (Peterson, 2018, p. 44), when we return to moral imperatives and take personal responsibility for our wellbeing.

\subsection{Steps towards restoration}

The following are steps towards the restoration of order. You can redeem yourself and earn your own salvation through sorting yourself out and developing the discipline to pursue a higher good.

1. Know yourself. Know "where you are, so you can start to chart your course" (p. 65).

2. Your life has significance. "You have a vital role to play in the unfolding destiny of the world" (p. 62).

3. Restore order to your life. "Bring the divine force of Hope to bear on the world" (p. 63).

4. Discipline yourself. Have the willpower to refine your personality, redirect your destination, and endure hardship. "He who has a why can bear almost any how" (Nietzsche, as quoted in Frankl, 1985).

5. Aim at a more spiritual future. "You could help direct the world, on its careening trajectory, a bit more toward Heaven and a bit more away from Hell" (p. 63).

6. Devote your life to something higher and bigger than yourself. "That would give you a Meaning, with a capital M. That would justify your miserable existence" (pp. 63-64).

7. Navigate between chaos and order. You can recreate order in the midst of chaos, experience happiness in the midst of miseries.

\subsection{Peterson's 12 Rules of Life}

The titles for his 12 rules of life are as follows:

1. Stand up straight with your shoulders back;

2. Treat yourself like someone you are responsible for helping;

3. Make friends with people who want the best for you;

4. Compare yourself to who you were yesterday, not to who someone else is today;

5. Do not let your children do anything that makes you dislike them;

6. Set your house in perfect order before you criticize the world;

7. Pursue what is meaningful (not what is expedient);

8. Tell the truth-or, at least, don't lie;

9. Assume that the person you are listening to might know something you don't;

10. Be precise in your speech; 
11. Do not bother children when they are skateboarding;

12. Pet a cat when you encounter one on the street.

All these rules are action-oriented, but together they identify the characteristics of a responsible, fully-functioning human being, who not only enjoys a productive, rewarding life, but also contributes to the wellbeing of humanity.

We can readily relate the above rules to major psychological concepts from Carl Rogers (1961), Abraham Maslow (1975, 1998), Viktor Frankl (1985), and Wong's (2016b) meaning therapy.

1. Face your miserable condition with courage and confidence.

2. Stop self-sabotaging and take good care of yourself, because life is precious.

3. Find friends who support your efforts in self-improvement.

4. Focus on improving yourself daily by aiming at your highest good.

5. Be responsible in teaching your children character and how to get along with others.

6. Bring order to your own life first before trying to change the world.

7. Value and choose what is meaningful, even when it demands sacrifice.

8. Value truthfulness and speak the truth as the backbone of your character.

9. Listen with humility and an open mind as a way to learn something.

10. Speak precisely about your intentions and concerns to minimize conflicts.

11. Let "boys be boys" and "girls be girls," accepting the reality of dominance hierarchies in various domains.

12. Accept that life is hard for everyone; therefore, be charitable and show kindness to all sentient beings.

\subsection{Research support for Peterson's main concepts}

The most common criticism against Peterson is that he does not have research support for many of his claims. Since the 12 Rules of Life is intended to be a self-help book, this might be part of the reason for the scanty presence of references to 12 Rules for Life in the research literature. Another reason is that, to the extent his rules are based on religious or mythological truth, it stands on its own legs without scientific support. Finally, some things are so intuitive and self-evident, such as "one needs to take responsibility for one's life" or "life is full of suffering," that support is superfluous; however, there is considerable research support for these concepts in the literature.

\subsection{Taking responsibility for one's life}

Peterson asks his readers not to beat themselves up. Rather, he challenges them to pull their weight conscientiously without complaint. This theme runs through the entire book:

To stand up straight with your shoulders back is to accept the terrible responsibility of life, with eyes wide open. It means deciding to voluntarily transform the chaos of potential into the realities of habitable order. It means adopting the burden of self-conscious vulnerability, and accepting the end of the unconscious paradise of childhood, where finitude and mortality are only dimly 
comprehended. It means willingly undertaking the sacrifices necessary to generate a productive and meaningful reality (it means acting to please God, in the ancient language) (Peterson, 2018, p. 27).

There is considerable research evidence on the importance of being responsible or conscientious in a world full of competition, dominance hierarchies, and unequal distribution of resources. It is supported by research in sociobiology (Gilbert, 2016; Wilson, 2000). It is also supported by extensive psychological research on self-determination (Deci \& Ryan, 2002), selfefficacy (Bandura, 1982), self-regulation (Bandura, 1991), self-control (Baumeister, Vohs, \& Tice, 2007), and internal locus of control (Rotter, 1966). Responsibility is also important in selfforgiveness and making reparations (Bell, Davis, Griffin, Ashby, \& Rice, 2017).

"Responsibility changes everything. ... The moment we decide that we are the ones who are capable of and responsible for changing things, everything shifts" (Izzo, 2012, p. 1). We not only need to choose the growth mindset (Dweck, 2007) but also the grit mindset of selfdiscipline, self-sacrifice, and courage for some greater good (Duckworth, 2016; Wong, 2014b, 2018b). In sum, without assuming personal responsibility, no one can survive and thrive as a healthy, independent adult. Similarly, no society can long survive, if its citizens do not have any sense of social responsibility or civil duty.

A lot of research has also shown that conscientiousness is the best predictor of school and career success (Ivcevic \& Brackett, 2014; Kern, Friedman, Martin, Reynolds, \& Luong, 2009). "Conscientiousness - a tendency to be responsible, hardworking, and organized-mattered at every point in the human life cycle. It even predicted how long people lived-with more accuracy than intelligence or background" (Ripley, 2013, p. 123). According to Clifton StrengthsFinders (Gallup University, 2004):

Your Responsibility theme forces you to take psychological ownership for anything you commit to, and whether large or small, you feel emotionally bound to follow it through to completion. Your good name depends on it. If for some reason you cannot deliver, you automatically start to look for ways to make it up to the other person. Apologies are not enough. Excuses and rationalizations are totally unacceptable (p. 60).

In sum, taking responsibility means to choose one's own preferred path, to pursue one's ideals, and to make painful sacrifices for something more important than one's own life. Peterson dares to paint responsibility in all its challenges and potentials. The alternative is unthinkableit means living out the rest of one's life in the living hell of unfulfilled promise, guilt, and regret.

\subsection{Suffering is the foundation for living a good life}

Suffering is an inevitable aspect of living, such as the need to toil, the travail of birth, sickness, accidents, disability, and death. Natural suffering needs to be accepted and embraced. 
However, intentional infliction of suffering on others for one's own gain or for its own sake is evil. Most of the horrible sufferings in the world come from human-inflicted suffering. The reality of suffering is so evident in human history and in the daily news, reflecting the fact that “each human being has an immense capacity for evil" (Peterson, 2018, p. 197).

Citing Christ, Buddha, Tolstoy, Dostoevsky, Nietzsche, and Frankl, Peterson argues that all great thinkers have framed their solutions by beginning with this acknowledgement. He puts forward that we do not need scientific proof that life is suffering, because every living human being can attest to that fundamental fact of life. He also posits that the human proclivity towards evil is also a self-evident truth: We pick up bad habits naturally, but it requires effort and a moral compass to become a good person.

For years, I have also been arguing that to understand happiness and wellbeing without considering the dark side of human existence is just as irresponsible as physicians and medical scientists focusing only on physical health without addressing the reality of pathogens and pain (Thin et al., 2017; Wong \& Bowers, 2018).

"The good life" is not one that is achieved through momentary pleasures or defensive illusions, but through meeting suffering head on and transforming it into opportunities for meaning, wisdom, and growth, with the ultimate objective being the development of the person into a fully-functioning, mature being. On this formula for happiness, age-old wisdom and modern science are in agreement (Emmons, 2003, p. 156).

The above passage is actually from Robert Emmons' (2003) book, The Psychology of Ultimate Concerns. Peterson has taken one step further beyond Emmons by claiming that ancient wisdom - in terms of myths, symbols, and religions - is more important than modern science in teaching us who we are (our human nature), where we came from (our cultural heritage), and how we should live (our moral compass for the present and the future) in order to advance wellbeing for oneself and humanity.

The difficulties intrinsic to life itself are sufficient to weaken and overwhelm each of us, pushing us beyond our limits, breaking us at our weakest point. Not even the best-lived life provides an absolute defence against vulnerability. ... The honest human spirit may continually fail in its attempts to bring about Paradise on Earth. It may manage, however, to reduce the suffering attendant on existence to bearable levels. The tragedy of Being is the consequence of our limitations and the vulnerability defining human experience (Peterson, 2018, p. 216).

In short, Peterson eschews the simplistic answers of American positive psychology and challenges us with the idea that existential truth and meaning can only be found in negotiating the right balance between life and death, happiness and misery, strength and weakness, and reason and faith. He even argues that the self-centered pursuit of happiness and success 
without any ethical concerns is by itself a course to evil and suffering. Meaning and happiness are experienced in striving for the right balance in the dialectical process: "Perhaps happiness is always to be found in the journey uphill" (Peterson, 2018, p. 94).

Down through history, many people have advocated the importance of focusing on the positive, from Seligman's (2002) positive psychology movement to the Chinese Communist Party's attempt to control the media (Bandurski, 2015; Lim \& Bergin, 2018). In the most extreme case, Buddha's father created an artificially positive environment where the young prince experienced only pleasures and beauty (Diamond Way Buddhism, 2018). No matter how laudable, these attempts will not work in the long run, because suffering is ubiquitous and universal, as Peterson has argued.

In psychology, the negativity bias in information processing, evaluation, and emotion has been well-documented (Baumeister, Bratslavsky, Finkenauer, \& Vohs, 2001; Kanouse \& Hanson, 1972; Lewicka, Czapinski, \& Peeters, 1992; Rozin \& Royzman, 2001). Our brains have evolved with this negativity bias because of its survival value. Wong and Weiner (1981) have also demonstrated a negative bias in spontaneous attribution search.

Scientific research has also shown that psychological pain is real and undeniable in terms of subjective phenomenological reports and objective neuro-physiological measures (Biro, 2010). Both Peterson and existential positive psychology believe that it is more adaptive to accept the reality of suffering and pain. Research shows that psychological pain, whatever the cause, can be best overcome by directly accepting it (Linehan, 1993), by confronting rather than suppressing it (Cioffi \& Holloway, 1993), and by transforming its meaning (López-Solà, Koban, \& Wager, 2018).

\subsection{The need for sacrifice and navigating between chaos and order}

Consistent with existential positive psychology, Peterson begins his analysis of meaning in life with the recognition that "pain and suffering define the world" (Peterson, 2018, p. 172). Given this bleak reality, Peterson (2018) argues that:

Sacrifice can hold pain and suffering in abeyance, to a greater or lesser degreeand greater sacrifices can do that more effectively than lesser. Of that, there can be no doubt. Everyone holds this knowledge in their soul. Thus, the person who wishes to alleviate suffering... will make the greatest of sacrifices... He will forego expediency. He will pursue the path of ultimate meaning. And he will in that manner bring salvation to the ever-desperate world (p. 172).

Different from traditional views of meaning, Peterson focuses on both the dynamic, dialectic, and integrative nature and process of meaning, as proposed by Wong's (2011, 2012b) dualsystems process of the good life. Thus, meaning is primarily not a static trait, but the process and outcome of a balancing and integrative act, characterized by the mature happiness of attunement, inner peace, and harmony (Wong, 2014c; Wong \& Bowers, 2018). This integrative 
process of individuation, according to Jung, may take continuous effort over a lifetime (Wong, 2009).

Peterson (2018) reasons that:

If there is something that is not good, then there is something that is good. If the worst $\sin$ is the torment of others, merely for the sake of the suffering produced - then the good is whatever is diametrically opposed to that. The good is whatever stops such things from happening (p. 198).

Thus, the fundamental ontological choice for each person is between good and evil, between meaning as the higher good, as opposed to the expediency of immediately gratifying carnal desires. To reduce suffering and seek the betterment of one's own life and other people's lives, we are responsible to choose the narrow path of following the former, in spite of the fact that we are constantly surrounded by evils and temptations.

Living a deeply fulfilling and meaningful life depends on both the depth of one's sacrifice and the height of one's mission. Peterson's greatest contribution to the positive psychology of meaning is to define meaning in life as sacrificing something of personal value at the present for a better future of greater value for both self and society. Thus, to serve something greater than the self is an empty statement if it does not demand the sacrifice of expediency and the risk of failures and dangers in serving a higher purpose.

The main consequence of attaining meaning goes beyond personal happiness, wellbeing, or success; rather, it is the development of a moral character strong enough to endure the storms of life and ennoble humanity in the process. A single courageous act of sacrifice can redeem the past and ennoble future generations. The retroactive and proactive benefits of meaning are clearly described by Frankl (1985).

The benefits of meaningful action also extend to your future, the people around you, and the broader world:

If you act properly, your actions allow you to be psychologically integrated now, and tomorrow, and into the future, while you benefit yourself, your family, and the broader world around you. Everything will stack up and align along a single axis. Everything will come together. This produces maximum meaning. ... Meaning trumps expedience. Meaning gratifies all impulses, now and forever. That is why we can detect it (Peterson, 2018, p. 199).

These new insights from Peterson call for new research strategies that incorporate both the precondition of suffering and the dialectic process of balancing between positives and negatives. Such research also calls for perspective studies and objective measures of adaptive success and wellbeing in overcoming difficult life circumstances. 


\section{Conclusions}

Peterson's leitmotif throughout the book is that life is suffering and human beings are fragile:

We can be damaged, even broken, emotionally and physically, and we are all subject to the depredations of aging and loss. This is a dismal set of facts, and it is reasonable to wonder how we can expect to thrive and be happy (or even to want to exist, sometimes) under such conditions (Peterson, 2018, p. 338).

This assessment of our human condition may have to do with his personal experience of helplessly seeing his two children suffering from illnesses, but reflects the position of many existential philosophers.

Therefore, the real challenge for positive psychology should be: How can we be at our best, when life is at its worst? How can we soar above all the hardships and traumas in a splendid display of the noble and defiant human spirit? How can we still experience joy and happiness, even when nothing goes right and our problems will not go away?

Peterson found his answer in accepting suffering as an inherent part of existence that requires no explanation; his "realization of the tight interlinking between vulnerability and Being was the best answer [he] had... there's something to be said for recognizing that existence and limitation are inextricably linked" (Peterson, 2018, p. 343). This is just the way life is. For everything good that exists, there must be some limitation. His other answer is that since life is so hard, be kind to all sentient beings and savour the simple pleasures in life: "If you pay careful attention, even on a bad day, you may be fortunate enough to be confronted with [the] small opportunities" of petting a cat, seeing a little girl dancing on the street, or having a good cup of coffee in a café that cares about its customers (Peterson, 2018, p. 353).

In an outstretched arm and the tender touch of a street cat, this simple symbolic gesture speaks volumes of Peterson's idea of heaven on earth. The good life is (a) finding a sanctuary of peace in the middle of a storm (Wong \& Bowers, 2018); (b) being connected with nature, with all sentient beings, and with the creator in perfect harmony; and (c) reaching out to the less advantaged with compassion. In that magic moment of connection, we become fully human as we transcend all egotistic interests and the differences that divide us in our attempt to embrace the sacredness of life as our common ground (Wong, 2016c).

It is so difficult for human beings to be happy, because people are complicated and life is hard. None of the theories and research findings will work for all people all the time, since all of us have to contend with so many issues, from political-economic problems, to relational, emotional, and health issues, to the demons dwelling in our unconscious.

Throughout the entire book, Peterson leads us through the vast terrain of suffering-the dark valleys and the steep mountains-without circumventing difficult controversial issues. With 
brutal acuity, he dismantles the ideology of cultural Marxism and postmodern feminism. He then articulates an alternative vision of personal responsibility; his 12 rules are designed to challenge people to bring order to their own lives in a chaotic world, so that they can grow and become what they were meant to be for themselves, their families, and their communities.

Strictly speaking, the 12 rules are not just an antidote to chaos, because the ultimate aim of life is not a stagnant state of security. When people are stuck in this state of complete equilibrium and stability, boredom and entropy will set in, unless they find something to strive for or fight against. Frankl (1985) has made the same point that full mental health or meaningful living depends on maintaining a healthy tension within us moving forward, rather than struggling to maintain an impossible-to-sustain equilibrium.

Like riding a bicycle, life is a balancing act between order and chaos. Peterson's 12 rules can be best understood as the life intelligence we all need to maintain a precarious dynamic balance between opposite forces as we move forward, in spite of the ups and downs of life.

Sorting out one's inner lobster and getting established in the world is only half of Peterson's vision of the good life. His neo-Darwinist view of struggling to improve one's ranking in the dominance hierarchy, even at its best, represents a shallow life, not strong enough to be sustained in times of trials and temptations. The other half of Peterson's vision has to do with sorting out one's spiritual core (whether it is the Buddha nature or the image of God) by discovering the still small voice of one's conscience and paying attention to time-tested truths based on collective ancient wisdom. This vertical transcendental dimension adds depth to our lives and enables us to aim at the highest good of ameliorating suffering and establishing heaven on earth.

Human progress depends on how we resolve the tension between our inner lobster and inner divinity. The following quote seems to suggest that, in the highest level of human development in an ideal society, the balance will tip in favour of the spiritual side:

Attend to the day, but aim at the highest good. Now, your trajectory is heavenward. That makes you hopeful. ... Who knows what existence might be like if all decide to strive for the best? Who knows what eternal heavens might be established by our spirits, purified by truth, aiming skyward, right here on the fallen Earth? (Peterson, 2018, pp. 111, 199).

Similarly, Maslow (1971) also recognized that self-actualization cannot be the end-game; in his revised needs hierarchy, the highest achievement is self-transcendence-losing one's self in serving a higher purpose and helping others to become their best. Thus, transition from selfactualization to self-transcendence represents a hero's ultimate balancing act, with one foot in ascending one's dominance hierarchy and the other foot in using one's gifts to serve others. That is why a compassionate and responsible liberal democracy offers freedom and the best hope to create an ideal existence. 
Peterson has a simple, pragmatic, and non-ideological way to transform individuals' lives and the world. His prescription reminds us of Covey's (1989) book, The 7 Habits of Highly Effective People, which is based on traditional Judeo-Christian values, the foundation of Western civilization. It is hard to argue against these time-tested values, which are the cornerstones of any civil society and the Western judicial system. Much of what Peterson has prescribed, such as speaking the truth and being kind to animals, are truisms that do not require scientific proof. I believe that Frankl's (1985) Man's Search for Meaning, Warren's (2014) The Purpose Driven Life, and Peterson's (2018) 12 Rules for Life have one thing in common, accounting for their extraordinary appeal: they all proceed from a spiritual worldview that recognizes the existence of God and a transcendental reality. From this perspective, they emphasize that the good life is not about what you can get from life, but what life demands from you-your responsibility to make a special contribution for the glory of God and for the wellbeing of humanity, based on the opportunities you craft for your life.

Peterson's book contributes to our understanding of both the depth and breadth of existential meaning, which is missing in the positive psychology of meaning (e.g., Smith, 2017). His existential-spiritual-dialectical view of the good life is the same as my existential positive psychology or PP 2.0 (Wong, 2011, 2012c). A few days ago, I actually dreamed of a great showdown pitching Seligman's (2011) PERMA against the existential dialectical approach of Peterson's 12 Rules or Wong's 12 Steps (Wong, 2016d) to determine which approach produces more lasting positive changes in people through a series of real-life challenges.

Given the continued replication crisis in psychology (Yong, 2018), it becomes increasingly difficult for positive psychology to claim that major life decisions about one's wellbeing and future direction should be based on empirical research findings. What is needed is to go beyond convenience sampling with college students and self-report methodology. We need more collaborative and holistic research methods that incorporate real life experiences of persons from varied cultural heritages (Wong, 2017).

I highly recommend 12 Rules for Life, because it presents many helpful insights for both researchers and practitioners in positive psychology. But I have to warn readers that some of his rants may be offensive to those who do not share his conservative leanings. Another weakness of this book, as I have alluded to earlier, is that it can be a frustrating experience wading through opaque passages. However, if you are willing to tolerate these minor limitations, you will be rewarded for reading this book.

\section{Author}

Paul Wong

Trent University, Peterborough, Canada

drpaulwong@gmail.com

\section{Publishing Timeline}

Received 7 January 2019

Accepted 8 January 2019 
Published 3 April 2019

\section{References}

Bandura, A. (1982). Self-efficacy mechanism in human agency. American Psychologist, 37(2), 122-147. https://doi.org/10.1037/0003-066X.37.2.122

Bandura, A. (1991). Social cognitive theory of self-regulation. Organizational Behavior and Human Decision Processes, 50(2), 248-287. https://doi.org/10.1016/0749-5978(91)90022-L

Bandurski, D. (2015, December 15). The CCP's "positive energy" obsession. China Media Project. http://chinamediaproject.org/2015/12/15/chinas-obsession-with-positive-energy/

Bartlett, T. (2018, January 17). What's so dangerous about Jordan Peterson? The Chronicle of Higher Education. https://www.chronicle.com/article/What-s-So-Dangerous-About/242256

Baumeister, R. F., Bratslavsky, E., Finkenauer, C., \& Vohs, K. D. (2001). Bad is stronger than good. Review of General Psychology, 5(4), 323-370. https://doi.org/10.1037/1089-2680.5.4.323

Baumeister, R. F., Vohs, K. D., \& Tice, D. M. (2007). The strength model of self-control. Current Directions in Psychological Science, 16(6), 351-355. https://doi.org/10.1111/j.1467-8721.2007.00534.x

Bell, C. M., Davis, D. E., Griffin, B. J., Ashby, J. S., \& Rice, K. G. (2017). The promotion of self-forgiveness, responsibility, and willingness to make reparations through a workbook intervention. The Journal of Positive Psychology, 12(6), 571-578. https://doi.org/10.1080/17439760.2016.1209545

Biro, D. (2010). Is there such a thing as psychological pain? And why it matters. Culture, Medicine, and Psychiatry, 34(4), 658-667. https://doi.org/10.1007/s11013-010-9190-y

Braaten, A., \& Huta, V. (2018). A preliminary exploration of how worldviews relate to eudaimonic and hedonic orientations. International Journal of Existential Psychology and Psychotherapy, 7(2), 11. http://journal.existentialpsychology.org/index.php/ExPsy/article/view/224/264

Carkner, G. E. (2016). The great escape from nihilism: Rediscovering our passion in late modernity. Abbotsford, BC: Infocus.

Cioffi, D., \& Holloway, J. (1993). Delayed costs of suppressed pain. Journal of Personality and Social Psychology, 64(2), 274-282. https://doi.org/10.1037/0022-3514.64.2.274

Covey, S. (1989). The 7 habits of highly effective people. New York, NY: Free Press.

Deci, E. L., \& Ryan, R. M. (Eds.). (2002). Handbook of self-determination research. Rochester, NY: University of Rochester Press.

Diamond Way Buddhism. (2018). The life of the Buddha. Diamond Way Buddhism. https://www.diamondway-buddhism.org/buddhism/buddha/

Duckworth, A. (2016). Grit: The power of passion and perseverance. New York, NY: Simon \& Schuster.

Dweck, C. S. (2007). Mindset: The new psychology of success. New York, NY: Ballantine Books.

Emmons, R. A. (2003). The psychology of ultimate concerns: Motivation and spirituality in personality. New York, NY: Gilford Press.

Frankl, V. E. (1985). Man's search for meaning (Revised \& updated ed.). New York, NY: Washington Square Press.

Frankl, V. E. (1986). The doctor and the soul: From psychotherapy to logotherapy (Revised \& expanded ed.). New York, NY: Random House.

Gallup University. (2004). Clifton StrengthsFinder ${ }^{T M}$ resource guide. Princeton, NJ: Gallup Organization.

Gilbert, P. (2016). Human nature and suffering. Hove, UK: Erlbaum.

Hill, P. C., \& Pargament, K. I. (2003). Advances in the conceptualization and measurement of religion and spirituality: Implications for physical and mental health research. American Psychologist, 58(1), 64-74. https://doi.org/10.1037/0003-066X.58.1.64

Ivcevic, Z., \& Brackett, M. (2014). Predicting school success: Comparing conscientiousness, grit, and emotion regulation ability. Journal of Research in Personality, 52, 29-36. https://doi.org/10.1016/j.jrp.2014.06.005

Ivtzan, I., Lomas, T., Hefferon, K., \& Worth, P. (2015). Second wave positive psychology: Embracing the dark side of life. London, England: Routledge.

Izzo, J. (2012). Stepping up: How taking responsibility changes everything. Oakland, CA: Berrett-Koehler. 
Johnson, M. (2018, July 23). The peculiar opacity of Jordan Peterson's religious views. Quillette. https:/quillette.com/2018/07/23/the-peculiar-opacity-of-jordan-petersons-religious-views/

Kanouse, D. E., \& Hanson, L. (1972). Negativity in evaluations. In E. E. Jones, D. E. Kanouse, S. Valins, H. H. Kelley, R. E. Nisbett, \& B. Weiner (Eds.), Attribution: Perceiving the causes of behavior. Morristown, NJ: General Learning Press.

Kern, M. L., Friedman, H. S., Martin, L. R., Reynolds, C. A., \& Luong, G. (2009). Conscientiousness, career success, and longevity: A lifespan analysis. Annals of Behavioral Medicine, 37(2), 154-163. https://doi.org/10.1007/s12160-009-9095-6

Koenig, H. G. (Ed.). (1998). Handbook of religion and mental health. San Diego, CA: Academic Press.

Köhler, N. (2018, May 9). Jordan Peterson's people are not who you think they are. Maclean's. https://www.macleans.ca/society/jordan-petersons-people-are-not-who-you-think-they-are/

Levin, Y. (2006). The moral challenge of modern science. The New Atlantis: A Journal of Technology and Society, Fall 2006, 32-46. https://www.thenewatlantis.com/docLib/TNA14-Levin.pdf

Lewicka, M., Czapinski, J., \& Peeters, G. (1992). Positive-negative asymmetry or 'When the heart needs a reason.' European Journal of Social Psychology, 22(5), 425-434. https://doi.org/10.1002/ejsp.2420220502

Lim, L., \& Bergin, J. (2018, December 7). Inside China's audacious global propaganda campaign. The Guardian. https://www.theguardian.com/news/2018/dec/07/china-plan-for-global-mediadominance-propaganda-xi-jinping

Linehan, M. M. (1993). Cognitive-behavioral therapy of borderline personality disorder. New York, NY: Guilford Press.

Lomas, T., \& Ivtzan, I. (2016). Second wave positive psychology: Exploring the positive-negative dialectics of wellbeing. Journal of Happiness Studies, 17(4), 1753-1768. https://doi.org/10.1007/s10902-015-9668-y

López-Solà, M., Koban, L., \& Wager, T. D. (2018). Transforming pain with prosocial meaning: A functional magnetic resonance imaging study. Psychosomatic Medicine, 80(9), 814-825. https://doi.org/10.1097/PSY.0000000000000609

Lukianoff, G., \& Haidt, J. (2018). The coddling of the American mind: How good intentions and bad ideas are setting up a generation for failure. New York, NY: Penguin Press.

Maslow, A. H. (1971). The farther reaches of human nature. New York, NY: Viking Press.

Maslow, A. H. (1975). Motivation and personality. New York, NY: Harper \& Row.

Maslow, A. H. (1998). Toward a psychology of being (3rd ed.). Hoboken, NJ: Wiley.

Meadows, R. (2018, September 17). Self authoring review: Sorting myself out with Dr Jordan Peterson. Deep Dish. https://thedeepdish.org/self-authoring-review-jordan-peterson/

Medin, D., Lee, C. D., \& Bang, M. (2014, October 1). Point of view affects how science is done: Gender and culture influence research on a fundamental level. Scientific American. https://www.scientificamerican.com/article/point-of-view-affects-how-science-is-done/

Mischel, W. (1966). Theory and research on the antecedents of self-imposed delay of reward. In B. A. Maher (Ed.), Progress in experimental personality research (pp. 85-131). New York, NY: Academic Press.

Murphy, R. (2018, December 7). Oh, the sweet irony of Jordan Peterson's fame. National Post. https://nationalpost.com/opinion/rex-murphy-oh-the-sweet-irony-of-jordan-petersons-fame

Peterson, J. B. (2016, July 31). Hierarchies of value as determinants of world-revelation. Keynote presented at the 2016 Meaning Conference, Toronto, ON.

Peterson, J. B. (2017, May 2). Banned lecture at Linfield College: Ethics and Free Speech [Video file]. https://youtu.be/AKHuxVvA7T8

Peterson, J. B. (2018). 12 rules for life: An antidote to chaos. Toronto, ON: Random House Canada.

Quester, J. P. (2018, December 2). What did Newton, Darwin, and Einstein think about God's existence? Owlcation. https://owlcation.com/humanities/Newton_Darwin_and_Einstein_on_God

Ripley, A. (2013). The smartest kids in the world: And how they got that way. New York, NY: Simon \& Schuster. 
Rogers, C. R. (1961). On becoming a person: A psychotherapist's view of psychotherapy. Boston, MA: Houghton Mifflin.

Rotter, J. B. (1966). Generalized expectancies for internal versus external control of reinforcement. Psychological Monographs: General E Applied, 80(1), 1-28. https://doi.org/10.1037/h0092976

Routledge, C. (2018). Supernatural: Death, meaning, and the power of the invisible world. New York, NY: Oxford University Press.

Rozin, P., \& Royzman, E. B. (2001). Negativity bias, negativity dominance, and contagion. Personality and Social Psychology Review, 5(4), 296-320. https://doi.org/10.1207/S15327957PSPR0504_2

Schiff, B. (2018, May 25). I was Jordan Peterson's strongest supporter. Now I think he's dangerous. The Star. https://www.thestar.com/opinion/2018/05/25/i-was-jordan-petersons-strongest-supporternow-i-think-hes-dangerous.html

Schippers, M. C., Scheepers, A. W., \& Peterson, J. B. (2015). A scalable goal-setting intervention closes both the gender and ethnic minority achievement gap. Palgrave Communications, 1, 15014. https://doi.org/10.1057/palcomms.2015.14

Seligman, M. E. P. (2002). Authentic happiness: Using the new positive psychology to realize your potential for lasting fulfillment. New York, NY: Simon \& Schuster.

Seligman, M. E. P. (2011). Flourish: A visionary new understanding of happiness and well-being. New York, NY: Free Press.

Slayback, Z. (2018, January 26). Why do intellectuals oppose Dr. Jordan B. Peterson? Age of Awareness. https://medium.com/age-of-awareness/why-do-intellectuals-oppose-dr-jordan-b-petersonf8b4e6dbe04c

Smith, E. E. (2017). The power of meaning: Crafting a life that matters. New York, NY: Crown.

Social Blade. (2018). Jordan B Peterson. https://socialblade.com/youtube/user/jordanpetersonvideos/

Taylor, C. (2007). A secular age. Cambridge, MA: Harvard University Press.

Thin, N., Tarragona, M., Wong, P. T. P., Jarden, R., Bartholomaeus, J., \& Jarden, A. (2017). [Review of the book The pursuit of human well-being: The untold global history, by R. J. Estes \& M. J. Sirgy]. International Journal of Wellbeing, 7(1), 84-92. https://internationaljournalofwellbeing.org/index.php/ijow/article/view/636

Warren, R. (2014). The purpose driven life. Philadelphia, PA: Running Press.

Wilson, E. O. (2000). Sociobiology: The new synthesis (25th anniversary ed.). Cambridge, MA: Harvard University Press.

Wong, P. T. P. (2009). The depth positive psychology of Carl Jung. In S. J. Lopez (Ed.), Encyclopedia of positive psychology (Vol. 1, pp. 545-546). Oxford, England: Wiley Blackwell.

Wong, P. T. P. (2011). Positive psychology 2.0: Towards a balanced interactive model of the good life. Canadian Psychology, 52(2), 69-81. https://doi.org/10.1037/a0022511

Wong, P. T. P. (2012a). The meaning mindset: Measurement and implications. International Journal of Existential Psychology and Psychotherapy, 4(1), 1-3.

http://journal.existentialpsychology.org/index.php/ExPsy/article/view/181/143

Wong, P. T. P. (2012b). Toward a dual-systems model of what makes life worth living. In P. T. P. Wong (Ed.), The human quest for meaning: Theories, research, and applications (2nd ed., pp. 3-22). New York, NY: Routledge.

Wong, P. T. P. (2012c). From logotherapy to meaning-centered counseling and therapy. In P. T. P. Wong (Ed.), The human quest for meaning: Theories, research, and applications (2nd ed., pp. 619-647). New York, NY: Routledge.

Wong, P. T. P. (2014a). Viktor Frankl's meaning seeking model and positive psychology. In A. Batthyány, \& P. Russo-Netzer (Eds.), Meaning in existential and positive psychology (pp. 149-184). New York, NY: Springer.

Wong, P. T. P. (2014b). The positive psychology of grit: The defiant power of the human spirit [Review of the film Unbroken, 2014]. PsycCRITIQUES, 60(25). https://doi.org/10.1037/a0039390

Wong, P. T. P. (2014c). From attunement to a meaning-centred good life. [Review of the book Happiness: A very short introduction, by D. Haybron]. International Journal of Wellbeing, 4(2), 100-105. https://doi.org/10.5502/ijw.v4i2.5 
Wong, P. T. P. (2016a). Existential positive psychology. International Journal of Existential Psychology and Psychotherapy, 6(1). http://journal.existentialpsychology.org/index.php/ExPsy/article/view/179/158

Wong, P. T. P. (2016b). Integrative meaning therapy: From logotherapy to existential positive interventions. In P. Russo-Netzer, S. E. Schulenberg, \& A. Batthyány (Eds.), Clinical perspectives on meaning: Positive and existential psychotherapy (pp. 323-342). New York, NY: Springer.

Wong, P. T. P. (2016c, October 18). The good life through polarity and transcendence (Part 1 of 2). The Virtue Blog. https://thevirtueblog.com/2016/10/18/the-good-life-through-polarity-andtranscendence-part-1/

Wong, P. T. P. (2016d). Meaning centered positive group intervention. In P. Russo-Netzer, S. Schulenberg, \& A. Batthyány (Eds.), Clinical perspectives on meaning: Positive and existential psychotherapy (pp. 423-445). New York, NY: Springer.

Wong, P. T. P. (2017). Meaning-centered approach to research and therapy, second wave positive psychology, and the future of humanistic psychology. The Humanistic Psychologist, 45(3), 207-216. https://doi.org/10.1037/hum0000062

Wong, P. T. P. (2018a, September 7). Decoding Jordan Peterson's 12 Rules for Life with Dr. Paul Wong and Dr. Gordon Carkner [Video file]. https://youtu.be/xsADJ4wdzSE

Wong, P. T. P. (2018b, May 11). Four-factor theory of true grit. Dr. Paul T. P. Wong. http://www.drpaulwong.com/four-factor-theory-of-true-grit/

Wong, P. T. P., \& Bowers, V. (2018). Mature happiness and global wellbeing in difficult times. In N. R. Silton (Ed.), Scientific concepts behind happiness, kindness, and empathy in contemporary society (pp. 112-134). Hershey, PA: IGI Global.

Wong, P. T. P., \& Reilly, T. (2017, August 15). Frankl's self-transcendence model and virtue ethics (Part 1 of 2). The Virtue Blog. https://thevirtueblog.com/2017/08/15/frankls-self-transcendence-modeland-virtue-ethics-part-1-of-2/

Wong, P. T. P., \& Weiner, B. (1981). When people ask "Why" questions and the heuristic of attributional search. Journal of Personality and Social Psychology, 40(4), 650-663. https://doi.org/10.1037/00223514.40.4.650

Yong, E. (2018, November 19). Psychology's replication crisis is running out of excuses. The Atlantic. https://www.theatlantic.com/amp/article/576223/ 